- FINANSE I PRAWO FINANSOWE.

- Journal of Finance and Financial Law •

Wrzesień/September 2017 • vol. 3(15): 41-52

http://dx.doi.org/10.18778/2391-6478.3.15.04

\title{
WIEDZA STUDENTÓW NA TEMAT PRODUKTÓW FINANSOWYCH I ŹRÓDŁA JEJ POCHODZENIA
}

\author{
Anna Magdalena Korzeniowska \\ Katedra Bankowości
}

Uniwersytet Marii Curie-Skłodowskiej w Lublinie

\begin{abstract}
Streszczenie
Celem niniejszego artykuły jest ocena wiedzy posiadanej przez studentów w zakresie produktów finansowych, z których korzystają lub planują korzystać uwzględniając źródła pochodzenia tej wiedzy. Analizę przeprowadzono w oparciu o badania na grupie studentów siedmiu uczelni Lublina (pięciu publicznych i dwóch prywatnych) zrealizowane $w$ formie ankiety. W tym celu wykorzystano podstawowe wskaźniki statystyczne takie jak: częstość, średnia, odchylenie standardowe ponieważ zestaw zebranych danych nie pozwolił na obliczenie korelacji pomiędzy oceną wiedzy o produktach a źródłami tej wiedzy co wykluczyło budowę modelu regresji.
\end{abstract}

Słowa kluczowe: młodzi dorośli, finanse osobiste, wiedza finansowa.

JEL Class: D14, D83. 


\section{WPROWADZENIE}

Analizując wskaźniki ubankowienia polskiego społeczeństwa zauważalne jest rosnące wraz z wiekem zaangażowanie Polaków w korzystanie z produktów bankowych. Wyjątkiem są osoby z grupy 55+, wśród których ubankowienie jest niższe, ale też rośnie w kolejnych latach $\mathrm{w}$ związku z dołączaniem do tej grupy, w wyniku procesu starzenia się, osób już ubankowionych [Koźliński 2013: 24]. Ubankowienie tzw. młodych dorosłych, czyli osób w wieku 18-24 lat jest poniżej średniej. Znaczący wpływ na ubankowienie ma poziom wykształcenia. Grupa społeczeństwa skupiająca osoby posiadające co najmniej wykształcenie średnie charakteryzuje się ponadprzeciętnym ubankowieniem oraz korzystaniem z więcej niż jednego produktu bankowego. Stąd w niniejszym artykule skupiono się na osobach studiujących w jednym $\mathrm{z}$ większych ośrodków akademickich w Polsce, jakim jest Lublin.

Korzystanie $\mathrm{z}$ produktów finansowych wymaga określonej wiedzy. Jak z każdym dobrem i usługą, których używanie wiąże się z ryzykiem, również w przypadku produktów finansowych, im wyższa wiedza o produkcie i świadomość zagrożeń związanych z jego stosowaniem, tym bezpieczniejszy klient. Dlatego też za cel artykuły przyjęto przeprowadzenie analizy wiedzy posiadanej przez studentów w zakresie produktów finansowych, z których korzystają lub planują korzystać uwzględniając źródła pochodzenia tej wiedzy. Przyjęto przy tym hipotezę, że wiedza osób posiadających zróżnicowane wykształcenie kierunkowe na temat produktów finansowych istotnie się różni.

\section{NABYWANIE WIEDZY O PRODUKTACH FINANSOWYCH, ISTOTA SOCJALIZACJI EKONOMICZNEJ}

Socjalizacja ekonomiczna to pojęcie, które odnosi się do przyswajania przez jednostkę wiedzy, pojęć, umiejętności, zachowań, postaw itd. związanych z otaczającym ją światem gospodarki [Wąsowicz-Kiryło 2008: 44]. Pojęcie socjalizacji ekonomicznej przede wszystkim kojarzy się z dziećmi i młodzieżą. Większość prac psychologów ekonomicznych $\mathrm{z}$ tego zakresu dotyczy najmłodszej grupy wiekowej. Jednak część autorów zauważa, że studenci to osoby, które intensywnie rozwijają się socjalnie i intelektualnie, a okres studiów to czas określania własnej ścieżki kariery i aspiracji ekonomicznych. Ci młodzi dorośli, chociaż z reguły nie są finansowo niezależni, często po raz pierwszy muszą zająć się codziennym zarządzaniem budżetem domowym [Shim i in. 2015: 29-38]. To powoduje konieczność stałej aktywności finansowej pozwalającej im rozwinąć wiedzę i umiejętności w zakresie funkcjonowania różnych produktów finansowych. 
Autorzy badań prowadzonych w krajach wysokorozwiniętych podkreślają znaczenie doświadczenia i wiedzy w zakresie funkcjonowania produktów finansowych, uzyskanych w młodości, dla stanu finansów osób dojrzałych i starszych [Herd i in. 2012: 411-435; Mishkin 2008]. Wskazują na istotny pozytywny związek pomiędzy pozyskaną wiedzą i doświadczeniami z produktami finansowymi w okresie nastoletnim lub wczesnej młodości a umiejętnością zarządzania finansami osobistymi w długim okresie w wieku dojrzałym.

Rozszerzeniem badań nad wiedzą na temat korzystania z produktów finansowych są rozważania dotyczące tzw. financial literacy. Jest to zjawisko definiowane jako zdolność użycia wiedzy i umiejętności w celu efektywnego zarządzania zasobami finansowymi dla zapewnienia sobie dobrobytu finansowego w ciągu całego życia [Knoll i Houts 2012: 381-410]. Okazuje się, że wiedza finansowa jest istotnym czynnikiem wpływającym na odpowiedzialne zarządzanie finansami osobistymi, a jej jakość zależy od źródeł pozyskiwania [Perry i Morris 2005: 299-313, http://10.0.4.87/j.1745-6606.2005.00016.x.:301].

\section{WIEDZA STUDENTÓW NA TEMAT PRODUKTÓW FINANSOWYCH}

Wybór Lublina jako miejsca prowadzenia badań wynikał przede wszystkim ze specyfiki demograficznej tego miasta akademickiego. Co prawda jest to dopiero dziewiąte miasto w Polsce pod względem liczby ludności, jednak według danych Urzędu Miasta Lublin w mieście studiuje ok. 70 tys. osób i stanowią one blisko 20\% mieszkańców [www1]. Tak duży odsetek studentów w całej populacji niewątpliwie oddziałuje na gospodarkę i kulturę miasta.

W celu przeanalizowania finansów studentów przeprowadzono badanie ankietowe metodą CAWI. Badanie objęło grupę 852 studentów studiujących na głównych uczelniach miasta tj. pięciu uczelniach publicznych: Uniwersytecie Marii Curie-Skłodowskiej, Uniwersytecie Medycznym, Uniwersytecie Przyrodniczym, Katolickim Uniwersytecie Lubelskim, Politechnice Lubelskiej, oraz dwóch niepublicznych: Wyższej Szkole Zarządzania i Administracji oraz Wyższej Szkole Ekonomii i Innowacji. Badani reprezentowali różne kierunki, tryby i roczniki studiów.

W pierwszej kolejności zbadano subiektywną wiedzę respondentów na temat wybranych instrumentów finansowych. W tym celu poproszono ich o wskazanie w pięciostopniowej skali, w której 1 oznaczało brak wiedzy, a 5 - wiedzę bardzo dobrą oceny własnej wiedzy dla każdego instrumentu finansowego oddzielnie (wykres 1). Wśród odpowiedzi najwyższe oceny zostały wskazane dla kart płatniczych: kredytowych i debetowych oraz podstawowych rachunków: oszczędnościowego i oszczędnościowo-rozliczeniowego, przy czym w przypad- 
ku ROR zaobserwować można największą rozbieżność wskazywanych ocen (odchylenie standardowe wynosi 1,47).

Pogłębione badanie wykazało, że ocena wiedzy o instrumentach finansowych rośnie wraz z czasem korzystania $\mathrm{z}$ nich. W większości przypadków korzystanie $z$ instrumentu już ponad 4 lata przekładało się na dobrą ocenę wiedzy (ocena 4). Niestety zbyt małą liczba korzystających wśród respondentów jest jednym z czynników powodujących niski poziom wyjaśnienia zależności między czasem posiadania produktu a wiedzą z nim związaną z użyciem modelu.

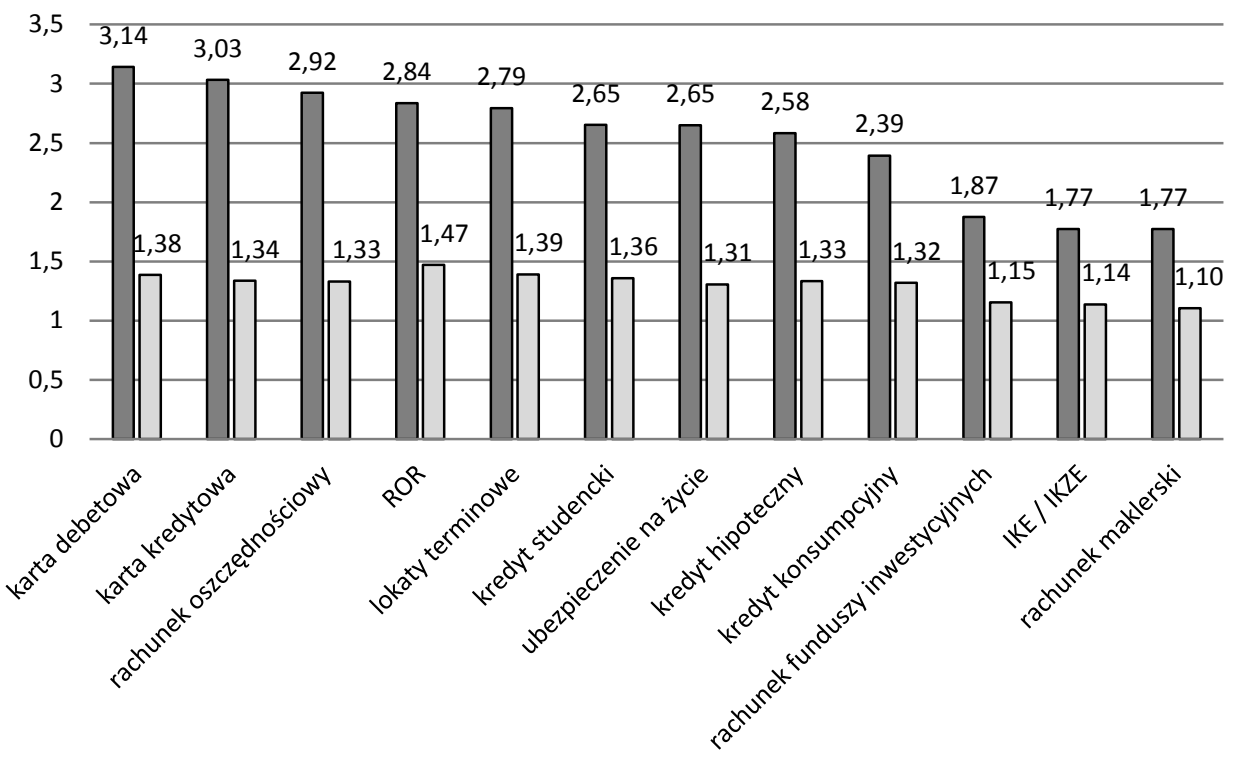

$\square$ Średnia $\quad \square$ Odchylenie standardowe

Wykres 1. Subiektywna ocena wiedzy studentów na temat instrumentów finansowych

Źródło: opracowanie własne na podstawie wyników badania ankietowego.

Ponieważ w badaniu brali udział studenci różnych kierunków studiów, więc przyjęto założenie, że ich poziom wiedzy ekonomicznej jest zróżnicowany. Szczególnie dotyczy to porównania studentów studiów ekonomicznych z innymi kierunkami. Dlatego też obliczono jaką średnią ocenę wiedzy o poszczególnych instrumentach finansowych deklarują odpowiednio studenci studiów z obszaru nauk ekonomicznych, z zakresu nauk ścisłych i technicznych, studiujący na kierunkach humanistycznych i społecznych i o sztuce $\mathrm{z}$ wyjątkiem nauk ekonomicznych oraz w ostatniej grupie, studentów z obszaru studiów nauk o życiu (tab. 1). 
Tabela 1. Deklarowana ocena wiedzy o wybranych instrumentach finansowych z uwzględnieniem obszaru studiów respondenta

\begin{tabular}{|l|c|c|c|c|c|}
\hline \multirow{2}{*}{$\begin{array}{l}\text { Rodzaj instrumentu } \\
\text { finansowego }\end{array}$} & $\begin{array}{c}\text { Brak } \\
\text { danych }\end{array}$ & $\begin{array}{c}\text { Nauki } \\
\text { ekono- } \\
\text { miczne }\end{array}$ & $\begin{array}{c}\text { Nauki } \\
\text { humanistycz- } \\
\text { ne, społeczne } \\
\text { i o sztuce }\end{array}$ & $\begin{array}{c}\text { Nauki ścisłe } \\
\text { i techniczne }\end{array}$ & $\begin{array}{c}\text { Nauki } \\
\text { o życiu }\end{array}$ \\
\hline ROR & 2,75 & 3,50 & 2,53 & 2,78 & 2,44 \\
\hline $\begin{array}{l}\text { Rachunek } \\
\text { oszczędnościowy }\end{array}$ & 2,81 & 3,51 & 2,78 & 2,70 & 2,60 \\
\hline $\begin{array}{l}\text { Kredyt } \\
\text { konsumpcyjny }\end{array}$ & 2,13 & 3,15 & 1,99 & 2,13 & 2,12 \\
\hline Kredyt hipoteczny & 2,38 & 3,11 & 2,43 & 2,30 & 2,38 \\
\hline Kredyt studencki & 2,63 & 2,91 & 2,45 & 2,49 & 2,65 \\
\hline Karta kredytowa & 2,73 & 3,44 & 2,90 & 2,83 & 2,88 \\
\hline Karta debetowa & 3,06 & 3,67 & 2,82 & 3,04 & 2,91 \\
\hline Lokaty terminowe & 2,75 & 3,53 & 2,45 & 2,53 & 2,48 \\
\hline Rachunek maklerski & 1,56 & 2,24 & 1,53 & 1,62 & 1,59 \\
\hline $\begin{array}{l}\text { Rachunek funduszy } \\
\text { inwestycyjnych }\end{array}$ & 1,81 & 2,33 & 1,67 & 1,71 & 1,69 \\
\hline $\begin{array}{l}\text { Ubezpieczenie na } \\
\text { życie }\end{array}$ & 3,19 & 2,97 & 2,64 & 2,37 & 2,50 \\
\hline IKE/IKZE & 1,75 & 2,32 & 1,45 & 1,63 & 1,55 \\
\hline
\end{tabular}

Źródło: opracowanie własne na podstawie wyników badania ankietowego.

W przypadku większości produktów ich ranking pod względem wiedzy respondentów posiadających różne wykształcenie kierunkowe jest podobny. Produkty inwestycyjne typu rachunek funduszy inwestycyjnych, rachunek maklerski oraz produkty długoterminowe, takie jak kredyt hipoteczny i IKE lub IKZE mają najniższe oceny, podczas gdy bardziej popularne karty płatnicze oraz rachunki oszczędnościowo-rozliczeniowe i rachunki oszczędnościowe osiągają wyższe oceny.

Nieco zróżnicowana jest sytuacja w przypadku ubezpieczeń na życie i kredytów studenckich. W przypadku ubezpieczeń znajdują się one na jednym $\mathrm{z}$ niższych miejsc $\mathrm{w}$ ocenie wiedzy przez studentów kierunków ekonomicznych, za to plasują się na czwartym miejscu wśród osób studiujących w zakresie nauk humanistycznych i społecznych. Najwyżej pod względem deklarowanej wiedzy kredyty studenckie są umiejscawiane przez studentów nauk o życiu, w tym osób studiujących na kierunkach lekarskich i farmacji. Być może spodziewane wysokie dochody po zakończeniu studiów ułatwiają im podjęcie decyzji o zaciąganiu zobowiązań. 
$\mathrm{Na}$ zakończenie wykorzystując test $\mathrm{F}$ (test Leven'a jednorodności wariancji) stwierdzono, że tylko w kilku przypadkach różnice średniej oceny wiedzy między studentami różnych kierunków studiów są nieistotne statystycznie (tab. 2).

Tabela 2. Brak istotnych statystycznie różnic w ocenie wiedzy o wybranych instrumentach finansowych pomiędzy studentami różnych obszarów wiedzy

\begin{tabular}{|l|l|}
\hline \multicolumn{1}{|c|}{ Rodzaj instrumentu finansowego } & Różnice między studentami (test F nieistotny) $\mathrm{p}<0,05$ ) \\
\hline ROR & Eko-HS, ST-NŻ \\
\hline Rachunek oszczędnościowy & ST-NŻ \\
\hline Kredyt konsumpcyjny & Eko-HS, Eko-ST, HS-ST \\
\hline Kredyt studencki & HS-NŻ \\
\hline Karta kredytowa & Eko-NŻ \\
\hline Karta debetowa & HS-NŻ, HS-ST \\
\hline Lokaty terminowe & HS-NŻ \\
\hline Rachunek maklerski & ST-NŻ \\
\hline Rachunek funduszy inwestycyjnych & ST-NŻ \\
\hline IKE/IKZE & ST-NŻ \\
\hline
\end{tabular}

gdzie:

Eko - studenci kierunków w obszarze nauk ekonomicznych,

HS - studenci kierunków w obszarze nauk humanistycznych, społecznych i o sztuce

z wyjątkiem nauk ekonomicznych,

ST - studenci kierunków w obszarze nauk ścisłych i technicznych,

NŻ - studenci kierunków w obszarze biologii i nauk o życiu.

Źródło: opracowanie własne na podstawie wyników badania ankietowego.

\section{POCHODZENIE WIEDZY STUDENTÓW NA TEMAT PRODUKTÓW FINANSOWYCH}

Wiedza na temat produktów finansowych może pochodzić z różnych źródeł. Jej dostawcami może być system edukacji, rodzina, media ogólnodostępne i specjalistyczne oraz same instytucje finansowe. Dobór źródeł poszukiwania informacji o produktach finansowych jest częściowo zależny od wieku i wykształcenia osób, które z nich korzystają. W przypadku osób młodych, szczególnie nastolatków i młodych dorosłych podstawowym źródłem informacji na różne tematy jest Internet. Źródło wiedzy może mieć też związek z jej jakością dlatego istotne jest rozpoznanie głównych mediów informacyjnych i dostarczanie do nich kompleksowej informacji, tak aby unikać błędnej komunikacji. 
Po dokonaniu analizy subiektywnego poziomu wiedzy studentów poddanych badaniu kolejnym analizowanym zagadnieniem stały się zatem źródła, z których korzystali respondenci poszukując informacji na temat produktów finansowych. Respondenci mogli deklarować korzystanie równocześnie z wielu źródeł spośród 8 wskazanych. Mogli także stwierdzić, że nie są zainteresowani tematem produktów finansowych i tę odpowiedź wybrało 13,6\% respondentów (wykres 2).

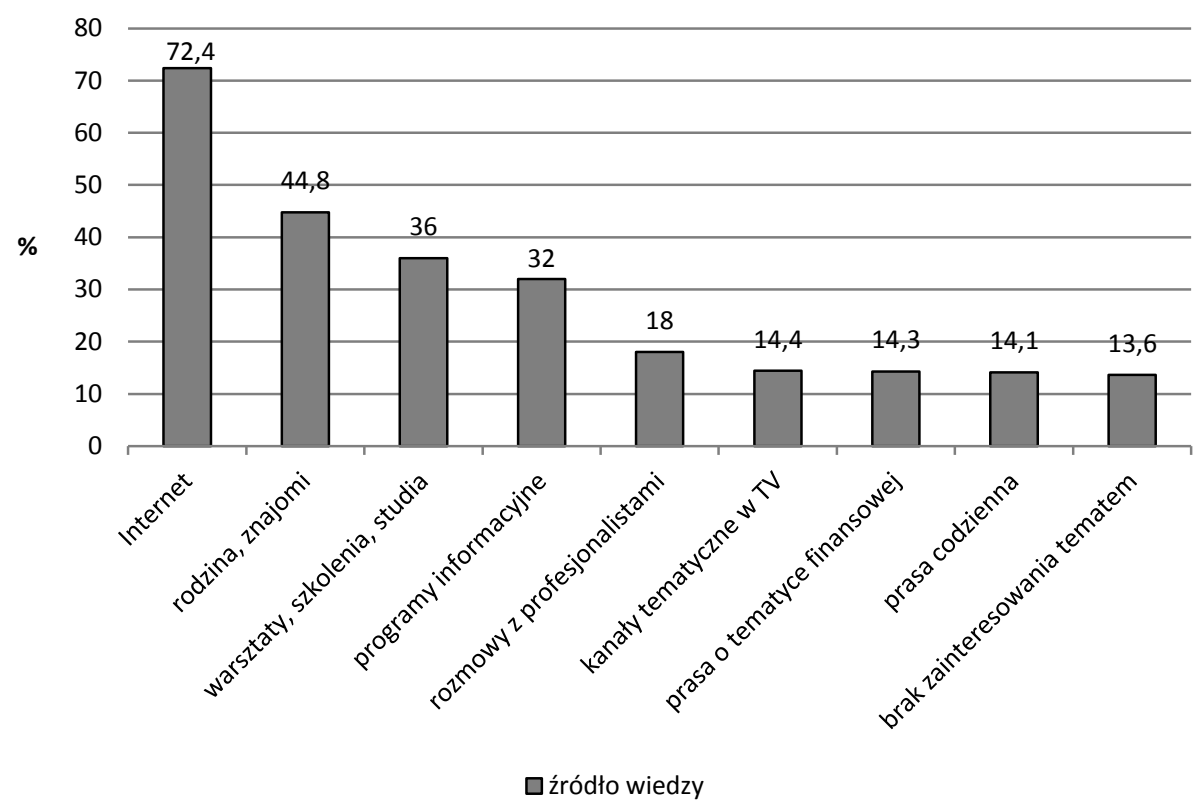

Wykres 2. Wykorzystywane źródła informacji finansowej przez studentów (\% respondentów)

Źródło: opracowanie własne na podstawie wyników badania ankietowego.

Zgodnie z oczekiwaniami jako najczęściej wykorzystywane źródło informacji respondenci wskazali Internet. Korzysta $\mathrm{z}$ niego w poszukiwaniu wiedzy na temat produktów finansowych ponad $72 \%$ badanych. Drugie miejsce pod względem liczby korzystających $\mathrm{z}$ tego źródła informacji, przypadło rodzinie i znajomym. $Z$ wiedzy osób bliskich jako doradców korzysta 44,8\% studentów. Ten sposób pozyskiwania wiedzy o produktach finansowych jest szczególnie istotny dla osób młodych. Doradztwo członków rodziny i znajomych ma m.in. istotny wpływ na wybór banku, przy zakładaniu pierwszego rachunku oszczędnościowo-rozliczeniowego, czy zakupie pierwszej karty płatniczej. 
$36 \%$ respondentów wskazało, że posiadaną wiedzę na temat instrumentów finansowych czerpie $\mathrm{z}$ warsztatów, szkoleń i studiów o tematyce finansowej, a 32\% z programów informacyjnych. Trzeba jednak uwzględnić, że wśród respondentów są przedstawiciele kierunków ekonomicznych, dla których studia są naturalnym źródłem informacji $\mathrm{w}$ tym obszarze. $\mathrm{Z}$ pozostałych źródeł wiedzy korzysta mniej niż $20 \%$ badanych osób.

Poszerzając analizę źródeł wiedzy wykorzystywanych przez studentów w zakresie produktów finansowych o kierunek studiów w jakim się kształcą obserwujemy wyraźne różnice pomiędzy studentami kierunków ekonomicznych a pozostałymi grupami (wykres 3). Studenci nauk ekonomicznych obok wyraźnie większego wykorzystywania warsztatów, szkoleń i studiów przede wszystkim wykazują zainteresowanie tematyką produktów finansowych. Chociaż $0,84 \%$ spośród nich zaznaczyło odpowiedź przeczącą temu stwierdzeniu. Jedyne wykorzystywane źródło informacji, w przypadku którego odsetek studentów nauk ekonomicznych jest niższy niż adeptów pozostałych nauk to rodzina i znajomi.

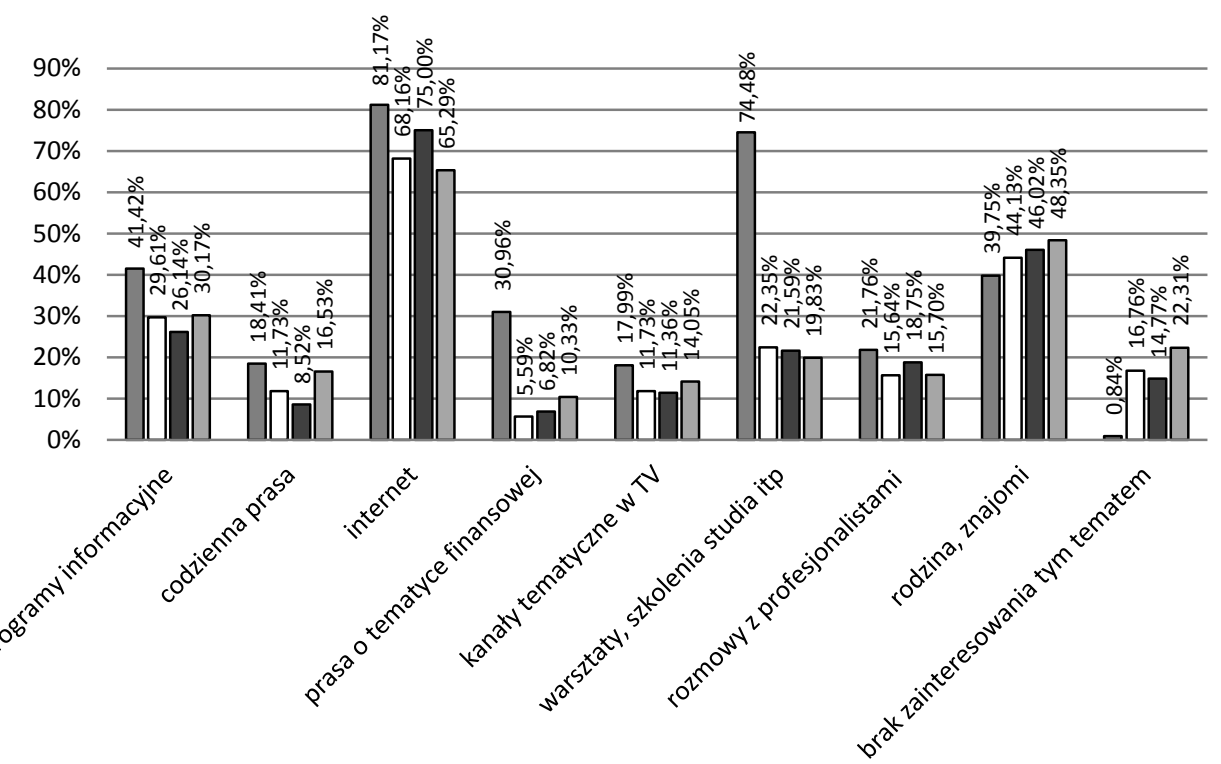

$\square$ nauki ekonomiczne $\square$ nauki humanistyczne i społeczne $\square$ nauki techniczne i ścisłe $\square$ nauki o życiu

Wykres 3. Wykorzystywane źródła informacji finansowej przez studentów z uwzględnieniem kierunków kształcenia (\% respondentów)

Źródło: opracowanie własne na podstawie wyników badania ankietowego. 
Nie budzi zaskoczenia także fakt, że studenci nauk technicznych i ścisłych, są drugą z kolei grupą wykorzystującą Internet i rozmowy z profesjonalistami, podczas gdy w odniesieniu do pozostałych źródeł wiedzy o produktach finansowych plasują się pomiędzy studentami nauk humanistycznych a tymi studiującymi nauki o życiu.

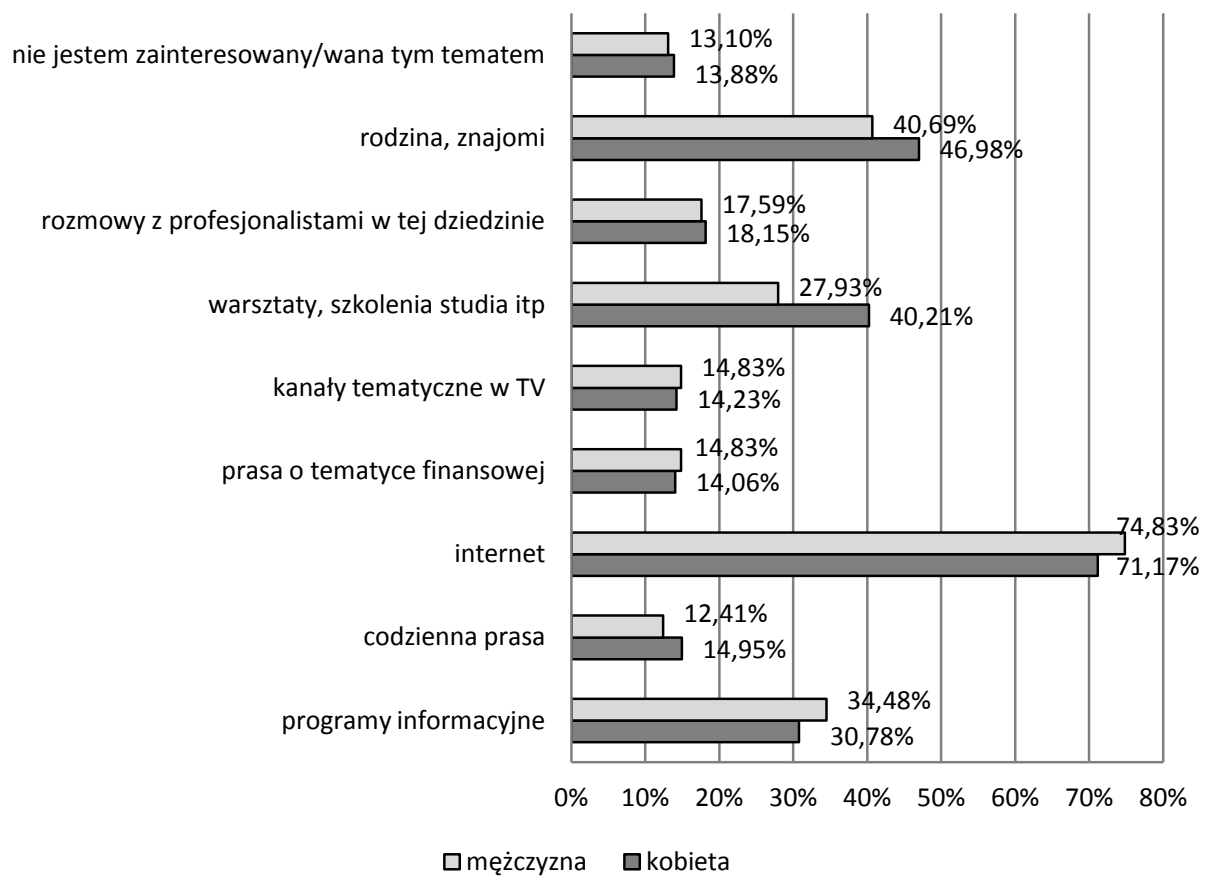

Wykres 4. Wykorzystywane źródła informacji finansowej przez studentów z uwzględnieniem płci respondentów

Źródło: opracowanie własne na podstawie wyników badania ankietowego.

Również uwzględniając płeć respondentów można zauważyć różnice w wykorzystywanych źródłach wiedzy i informacji na temat produktów finansowych (wykres 4). Kobiety częściej niż mężczyźni korzystają z porad rodziny i znajomych, warsztatów i studiów oraz $\mathrm{z}$ wiadomości zamieszczanych $\mathrm{w}$ prasie codziennej.

Struktura danych nie pozwoliła na stworzenie funkcji regresji pokazującej zależność pomiędzy wykorzystywaniem produktów finansowych, wiedzą o nich oraz wykorzystywanymi źródłami informacji o tych produktach. Można jednak zbadać, jaki średni poziom deklarowanej wiedzy na temat poszczególnych produktów w odniesieniu do źródła pochodzenia tej wiedzy. Analiza wskazuje, że 
największej wiedzy dostarczają, poza warsztatami, szkoleniami i studiami, prasa o tematyce finansowej oraz rozmowy z profesjonalistami (tab. 3). Mimo największego wykorzystywania Internetu do poszukiwania wiedzy na temat produktów finansowych, średni poziom wiedzy deklarowanej przez korzystających $\mathrm{z}$ tego medium jest stosunkowo niski. Jednak najmniej efektywne pod względem dostarczania wiadomości okazują się rozmowy z rodziną i znajomymi.

Tabela 3. Średnia ocena wiedzy studentów na temat wybranych produktów finansowych z uwzględnieniem źródła jej pochodzenia

\begin{tabular}{|c|c|c|c|c|c|c|c|c|c|}
\hline $\begin{array}{l}\text { Instrument } \\
\text { finansowy }\end{array}$ & 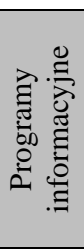 & 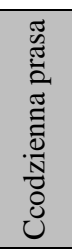 & 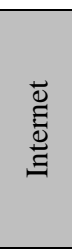 & 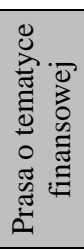 & 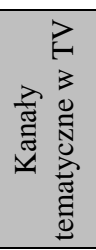 & 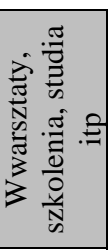 & 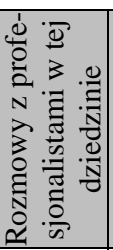 & 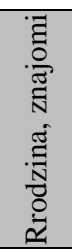 & 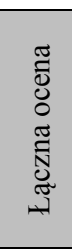 \\
\hline (ROR) & 3,17 & 3,16 & 2,94 & 3,64 & 3,22 & 3,37 & 3,52 & 2,72 & 2,83 \\
\hline $\begin{array}{l}\text { Rachunek } \\
\text { oszczędnościowy }\end{array}$ & 3,27 & 3,28 & 3,04 & 3,67 & 3,16 & 3,46 & 3,60 & 2,91 & 2,92 \\
\hline $\begin{array}{l}\text { Kredyt } \\
\text { konsumpcyjny }\end{array}$ & 2,78 & 2,79 & 2,46 & 3,32 & 2,81 & 3,01 & 2,95 & 2,31 & 2,39 \\
\hline $\begin{array}{l}\text { Kredyt } \\
\text { hipoteczny }\end{array}$ & 2,92 & 3,04 & 2,66 & 3,21 & 2,90 & 3,16 & 3,09 & 2,65 & 2,58 \\
\hline Kredyt studencki & 2,84 & 2,98 & 2,70 & 3,20 & 2,78 & 3,04 & 3,09 & 2,75 & 2,65 \\
\hline Karta kredytowa & 3,26 & 3,35 & 3,13 & 3,48 & 3,29 & 3,48 & 3,47 & 3,18 & 3,03 \\
\hline Karta debetowa & 3,37 & 3,39 & 3,24 & 3,80 & 3,47 & 3,64 & 3,61 & 3,22 & 3,14 \\
\hline $\begin{array}{l}\text { Lokaty } \\
\text { terminowe }\end{array}$ & 3,00 & 3,22 & 2,89 & 3,52 & 3,03 & 3,44 & 3,45 & 2,82 & 2,79 \\
\hline $\begin{array}{l}\text { Rachunek } \\
\text { maklerski }\end{array}$ & 1,93 & 1,97 & 1,78 & 2,36 & 1,94 & 2,13 & 2,19 & 1,69 & 1,77 \\
\hline $\begin{array}{l}\text { Rachunek } \\
\text { funduszy } \\
\text { inwestycyjnych }\end{array}$ & 2,01 & 2,07 & 1,90 & 2,41 & 2,06 & 2,34 & 2,39 & 1,81 & 1,87 \\
\hline $\begin{array}{l}\text { Ubezpieczenie na } \\
\text { życie }\end{array}$ & 2,87 & 2,91 & 2,72 & 3,01 & 2,96 & 3,14 & 3,24 & 2,80 & 2,65 \\
\hline IKE/IKZE & 1,88 & 2,05 & 1,81 & 2,41 & 1,93 & 2,21 & 2,21 & 1,71 & 1,77 \\
\hline
\end{tabular}

Źródło: opracowanie własne na podstawie wyników badania ankietowego.

\section{PODSUMOWANIE}

Rezultaty wskazują, że wiedza młodych ludzi na temat produktów finansowych jest relatywnie niska, co nie jest korzystnym zjawiskiem zarówno dla przyszłej stabilności i bezpieczeństwa ich finansów prywatnych, jak i dla gospodarki jako 
całości. Z tego względu wskazane jest wprowadzenie aspektów dotyczących finansów prywatnych do programów nauczania już od wczesnych etapów edukacji.

Co prawda studenci mogą mieć niskie zapotrzebowanie na część produktów ubezpieczeniowych oraz nie mieć możliwości finansowych pozwalających na korzystanie z produktów inwestycyjnych, szczególnie tych obciążonych wyższym ryzykiem. Jednak dla ich przyszłego zarządzania finansami prywatnymi powinni posiadać wiedzę pozwalającą podejmować świadome decyzje. Wiedza o różnych instrumentach, ich funkcjonowaniu, rentowności, obciążeniu ryzykiem pozwala na racjonalne kształtowanie całego portfela finansowego osoby fizycznej w jej cyklu życia, a to przekłada się na stabilność i bezpieczeństwo finansów prywatnych osób dojrzałych.

Badanie potwierdziło przyjętą hipotezę o istnieniu istotnych różnic pomiędzy osobami o różnym poziomie wiedzy finansowej wynikającym z wybranego kierunku kształcenia. Najmniejsze różnice, a w zasadzie brak różnic statystycznie istotnych występuje przede wszystkim w przypadku produktów podstawowych, najbardziej powszechnych jakimi są rachunek oszczędnościoworozliczeniowy i kredyt konsumpcyjny. Im produkty rzadziej używane przez studentów, tym różnice w deklarowanej wiedzy na ich temat są większe.

Powyższe szczególnie wskazuje na konieczność kształcenia finansowego na wcześniejszych niż studia etapach edukacji, kiedy programy nauczania są względnie podobne, z wyjątkiem przedmiotów kierunkowych. Takie działania będą sprzyjały zapewnieniu równego, świadomego dostępu do rynku i ochrony przed ryzykiem dla wszystkich klientów instytucji finansowych, a nie tylko dla absolwentów studiów w dziedzinie nauk ekonomicznych i osób szczególnie zainteresowanych tematyką ekonomii.

\section{BIBLIOGRAFIA}

Herd P., Holden K., Yung Ting Su, 2012, The Links between Early-Life Cognition and Schooling and Late-Life Financial Knowledge, ,Journal of Consumer Affairs”, no. 46, http://10.0.4.87/ j.1745-6606.2012.01235.x.

Knoll M.A.Z., Houts C.R., 2012, The Financial Knowledge Scale: An Application of Item Response Theory to the Assessment of Financial Literacy, „Journal of Consumer Affairs”, no. 46, http://10.0.4.87/j.1745-6606.2012.01241.x.

Koźliński T., 2013, Zwyczaje płatnicze Polaków, NBP, Warszawa, maj.

Mishkin F., 2008, The Importance of Economic Education and Financial Literacy, Speech before the Federal Reserve Board at the Third National Summit on Economic and Financial Literacy, Washington, DC.

Perry V.G., Morris M.D., 2005, Who Is in Control? The Role of Self-Perception, Knowledge, and Income in Explaining Consumer Financial Behavior, „Journal of Consumer Affairs”, no. 39, http://10.0.4.87/j.1745-6606.2005.00016.x>. 
Shim S., Serido J., Tang Ch., Card N., 2015, Socialization Processes and Pathways to Healthy Financial Development for Emerging Young Adults, „Journal of Applied Developmental Psychology", no 38, http://dx.doi.org/10.1016/j.appdev.2015.01.002.

Wąsowicz-Kiryło G., 2008, Psychologia finansowa. O pieniądzach $w$ życiu człowieka, Difin, Warszawa.

[www1] http://lublin.eu/biznes-i-nauka/nauka/potencjal-edukacyjny-miasta/15.02.2016.

\title{
STUDENTS' KNOWLEDGE ON FINANCIAL PRODUCTS AND ITS SOURCES
}

\begin{abstract}
The aim of this article is to assess the students' knowledge on financial products, they use or they are going to use, taking into account this knowledge sources. The analysis was based on the research carried out on the sample group of students of selected seven universities in Lublin. The method used were simple statistical measures as collected data disabled usage of the regression model.
\end{abstract}

Keywords: young adults, personal finance, financial knowledge. 